\title{
Analysis of the Influence of River Flow Engineering Upstream Areas on Sediment Transport in the Downstream Areas
}

\author{
Alfisalam Ghifari Mustafa*, Siti Murniningsih, Dwita Sutjiningsih \\ Department of Civil Engineering, Faculty of Engineering, Universitas Indonesia, Depok, West Java, Indonesia
}

Received February 25, 2020; Revised June 24, 2020; Accepted July 7, 2020

Copyright $\odot 2020$ by authors, all rights reserved. Authors agree that this article remains permanently open access under the terms of the Creative Commons Attribution License 4.0 International License

\begin{abstract}
Flooding is one of the common problems in Jakarta, and one of its causes is the overflow of the Pesanggrahan River. To overcome it, the Jakarta Provincial Government in 2013 normalized the river. However, several studies show that normalization results in channel instability on sediment transport. The purpose of this research is to analyze the effect of river normalization in upstream areas on sediment transport in the downstream regions of the section that is reviewed. The identification of changes in river flow before and after Normalization was carried out based on data from the Central Office of River Region Ciliwung-Cisadane, Ministry of Public Works. HEC-RAS is used to simulate sediment transport in the river segment before and after Normalization. The results are used to determine cross-section changes due to sediment transport and to determine the water level of the river. From the water level, the hydraulic radius can be calculated and then carried out sediment transport calculation using Ackers-White equation since the equation using grain distribution from range $0.02-4.94$ $\mathrm{mm}$. From the calculation, it can be seen that sediment transport at the upstream point increases 155.11 tons/year, at the middle point increases 89.64 tons/year, and at the downstream point decreases 0.28 tons/year.
\end{abstract}

Keywords Ackers-White, Flood, Normalization, Pesanggrahan River, Sediment Transport

\section{Introduction}

The geometric and planform shapes of rivers are determined by characteristics of two basic phenomena, hydraulics of flow with its sediment transport (Mohammed, Alturfi, \& Shlash, 2018). Sediment transport is one of the natural factors that form the morphology of the channel
(Soar \& Thorne, 2001). Normalization of the river to change river conditions with specific dimensions, usually by widening the river, creating concrete walls, and straightening the river (Brookes, 1988). Channelisation is the term used to embrace all processes of river channel engineering for flood control, drainage improvement, maintenance of navigation, reduction of bank erosion, or relocation for highway construction (Brookes, 1988). Pesanggrahan River is one of the rivers that has been changed from its original form. Normalization is carried out by the government to deal with flooding, which often happens in the area around the river.

According to the Head of the Center for Information and Public Relations Data of the National Disaster Management Agency, the floods that occurred in settlements around the Pesanggrahan River happened as a result of the water catchment areas that are not comparable with the built-up areas in the watershed. As many as $70 \%$ of the built area of the basin consists of $45 \%$ of dense settlements scattered in the downstream regions, from Kebayoran Lama, Kebon Jeruk, and Kedoya West Jakarta, while the green area is only about $7 \%$. Provincial Government of Jakarta and the Ministry of Public Works implemented the Normalization of the Pesanggrahan River from the end of 2013 to 2014. Normalization in the Pesanggrahan River is $26.7 \mathrm{~km}$ in length with the type of work done is widening and concreting the canal and making cut off to straighten the flow around the Cipulir area. By normalizing the river, it is expected that $50 \%$ of flooding can be overcome.

However, several studies show that river normalization has several disadvantages (White, Bettes, \& Shiqiang, 1986). Some researchers suggested that Normalization has disadvantages, one of which is channel instability in sediment transport (Fondriest Environmental, Inc, 2014). Instability occurs because of the disruption of the natural process of channel formation resulting in an imbalance 
between sediment supply and its capacity (Brookes, 1988). Sediment transport is the movement of organic and inorganic particles by the flow of water (The Federal Interagency Stream Restoration Working Group, 2001). Since sediment transport is one of the natural factors that form the morphology of the channel that in the Normalization of the river, it must be known the impact on sediment transport. Based on the problem, the present study was conducted to analyze the impact of the Normalization of the upstream river channel towards downstream sediment transport, with the location of Pesanggrahan River in Jakarta being used as a case study.

\section{Materials}

In this study, the daily discharge that occurs for one year on the available data will be calculated as the dominant discharge. Dominant discharge or channel-forming discharge is defined as a theoretical discharge that forms the geometry of the river channel and can be used as a long-term natural hydrograph (US Army Corps of Engineer, 2000). Dominant discharge is a debit that can adjust the balance between the movement of sediment and water so as to produce the shape of the reservoir and riverbed bottom (Ward, D'Ambrosio, \& Witter, 2008). Dominant discharge is the middle value of the discharge, which occurs annually (Blench, 1957). In calculating the dominant monthly discharge, Weibull's equation is used to find out the flow discharge that has an equal or exceeded $50 \%$ chance (Prins A., 1969).

$$
P_{50}=\frac{m}{n+1} \times 100 \%
$$

Where:

$\mathrm{P}=$ Opportunities to be equaled / exceeded (\%)

$\mathrm{m}=$ Rank

$\mathrm{n}=$ Amount of Data
From these equations, it can be known that the value of discharge data is close to 50\% (Benson \& Thomas, 2010). Therefore, five results that are close to the magnitude of the opportunity have been selected. The equation is used for both daily discharge data in 2010 and 2016 so that the dominant discharge every month in both years can be found. Table 1 shows the dominant discharge of the Pesanggrahan River in 2010 and 2016.

Sediment data obtained from direct sampling at 3 points along the river segment reviewed, that is the upstream, middle, and downstream section as seen from Figure 1. Two samples which have $2 \mathrm{~kg}$ weight, are taken from each point at the right and the left side of the riverbank. Sediment data obtained from the field are tested in the soil mechanics laboratory to obtain grain gradation from the sediment.

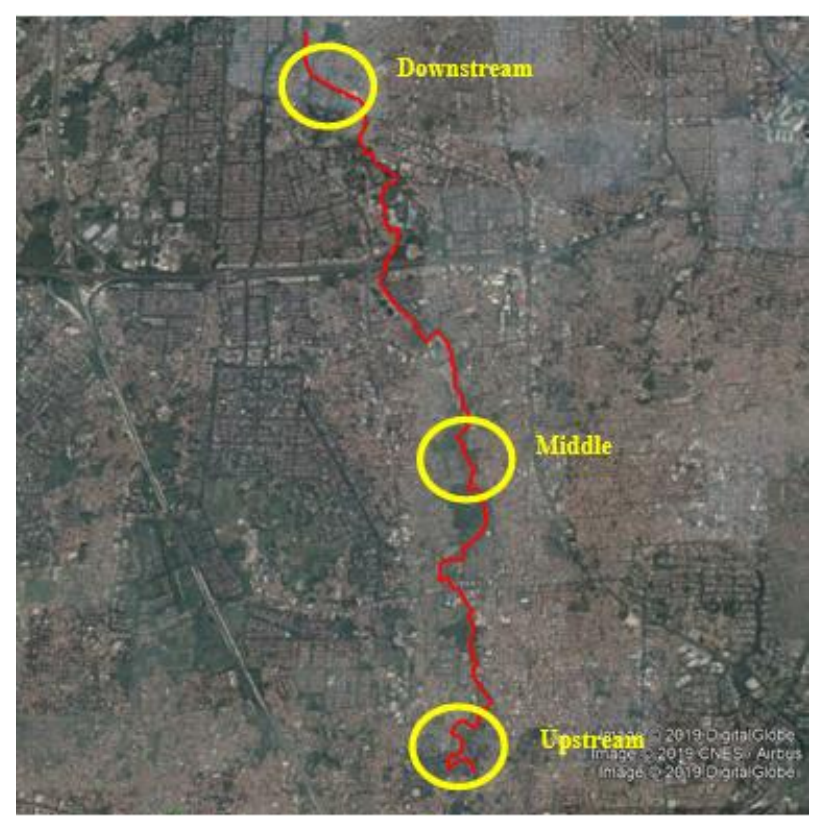

Figure 1. Sediment sampling locations

Table 1. Dominant discharge $\left(\mathrm{m}^{3} / \mathrm{s}\right)$

\begin{tabular}{ccccccccccccc}
\hline & Jan & Feb & Mar & Apr & May & Jun & Jul & Aug & Sep & Oct & Nov & Des \\
\hline 2010 & 83.9 & 104.8 & 94.4 & 78.9 & 81.1 & 85.5 & 82.8 & 84.4 & 99.4 & 90.3 & 86.4 & 85.2 \\
2016 & 94.4 & 120.6 & 89.8 & 95.6 & 95 & 92.1 & 99.4 & 88.5 & 88.4 & 87.3 & 85.5 & 76.6 \\
\hline
\end{tabular}


From Figure 2, it can be seen the gradation of the grain sediment samples for each test point that is upstream, middle, and downstream. Gradation of the sediment is one of the data used to carry out sediment transport simulations using HEC - RAS (US Army Corps of Engineer, 2016).

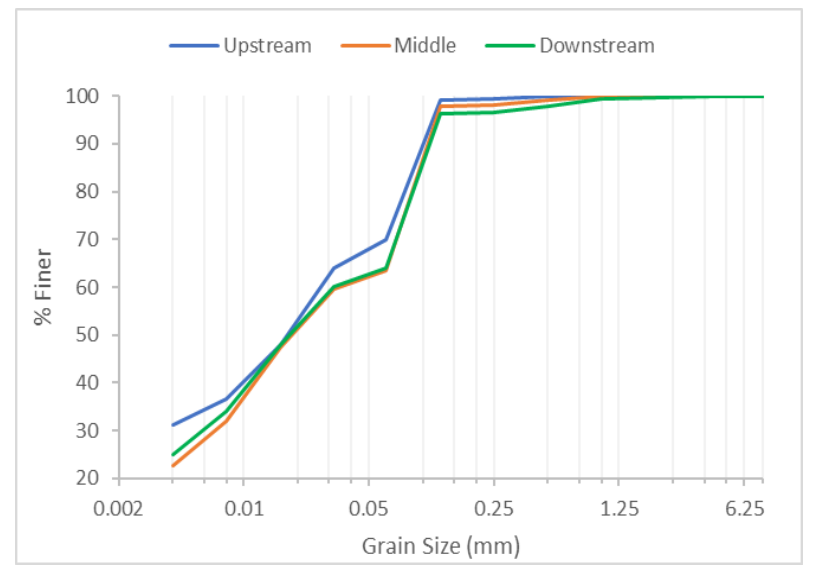

Figure 2. Gradation curves of sediment grains

Based on Figure 2, the percentage of soil type from each Sample can be known for every distribution of soil type contained. By using the soil type classification table based on grain diameters, the percentage of clay, silt, sand, and gravel can be determined (Craig, 2004).

Table 2. Soil type percentage based on grain diameter

\begin{tabular}{ccccc}
\hline $\begin{array}{c}\text { Soil } \\
\text { Type }\end{array}$ & $\begin{array}{c}\text { Diameter } \\
(\mathbf{m m})\end{array}$ & $\begin{array}{c}\text { Upstream } \\
\text { Sample } \\
(\boldsymbol{\%})\end{array}$ & $\begin{array}{c}\text { Middle } \\
\text { Sample } \\
(\boldsymbol{\%})\end{array}$ & $\begin{array}{c}\text { Downstream } \\
\text { Sample (\%) }\end{array}$ \\
\hline Clay & $\mathrm{D}<0.02$ & 21.5 & 14.56 & 17.5 \\
Silt & $0.02<\mathrm{D}<0.05$ & 48.5 & 48.94 & 46.5 \\
Sand & $0.5<\mathrm{D}<2$ & 30 & 36.5 & 36 \\
Gravel & $\mathrm{D}<75$ & 0 & 0 & 0 \\
\hline
\end{tabular}

It can be seen from Table 2 that the type of clay and silt soil of the sediment tends to decrease while sand tends to increase. This is less in line with the existing theory that the number of sediment particles with smaller diameter tends to increase from upstream to downstream due to reduction of the river flow velocity (The Federal Interagency Stream Restoration Working Group, 2001).

Based on geometry data obtained from the Central Office of River Region Ciliwung-Cisadane, the differences between the rivers before normalized and after normalized can be seen. The differences can be seen from the longitudinal profile and cross section of the river section studied. Normalization causes changed the river length where the length of the river before Normalization was $10,127 \mathrm{~m}$ and after Normalization became $9,029 \mathrm{~m}$. It happened because there was straightening and cut off work on several river sections. Figure 3 shows the differences between the river before and after normalized.

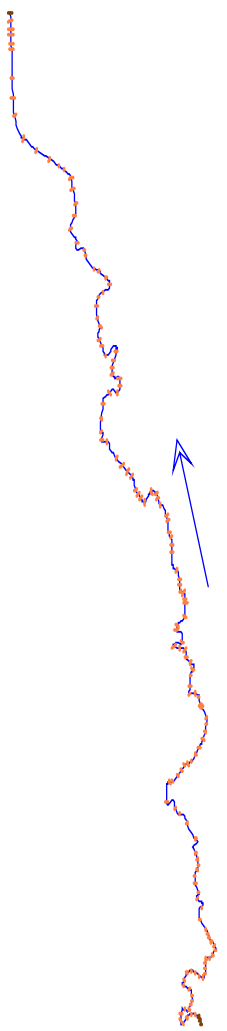

(a)

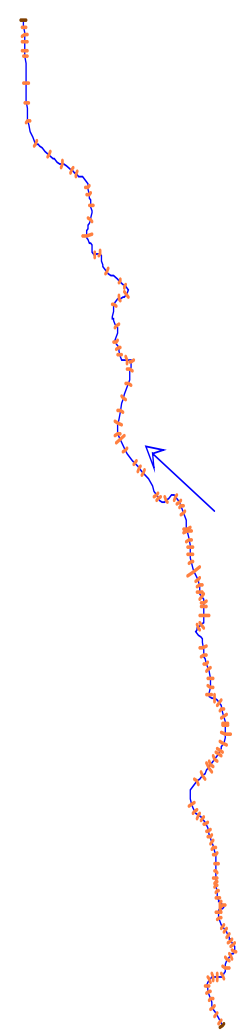

(b)
Figure 3. The differences between river flow (a) before Normalization and (b) after Normalization

It can be seen from Figure 3 that there are some sections of the river which had been cut off. It causes changes in the length of the river and also affects the slope of the river. The slope of the river is increased along with the shortening of the river (Prins I. A., 1970). Figure 4 shows the changes in the main channel distance where the length after Normalization is shorter and causes the river slope to becoming steeper.

In addition to changing the river in a longitudinal direction, Normalization also changes the shape of the cross-section of the river (Strahler, 1964). Those changes can be in the form of widening, deepening, and concreting around the cross-section (Worcester, 1948). Figure 5 shows the difference of cross-sections shape of the upstream section, middle section, and downstream section before and after Normalization. 


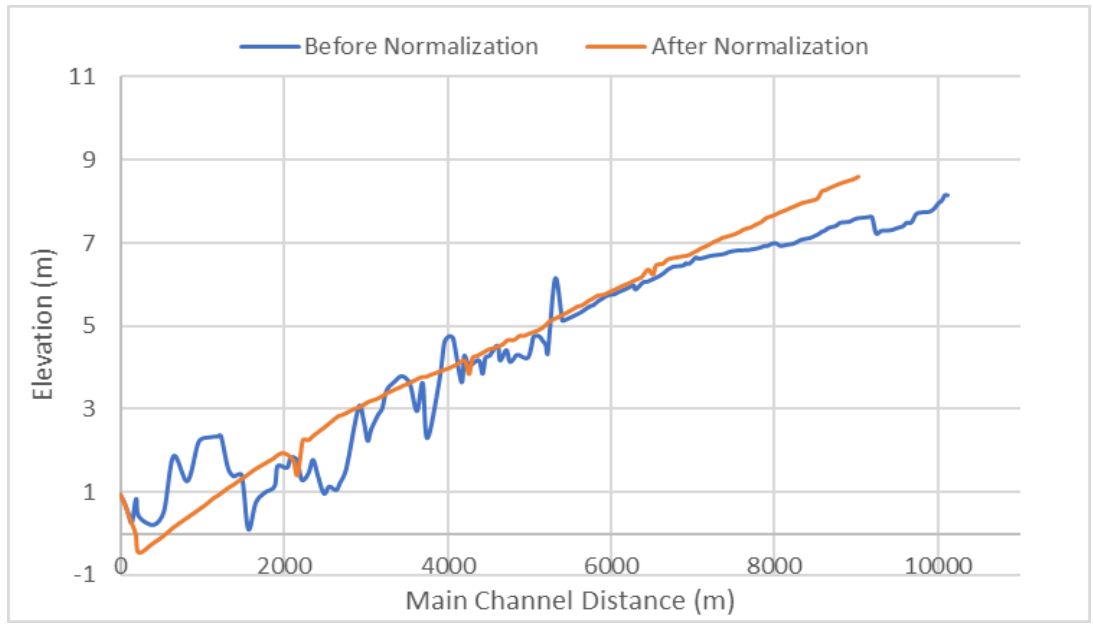

Figure 4. The changes in bottom slope

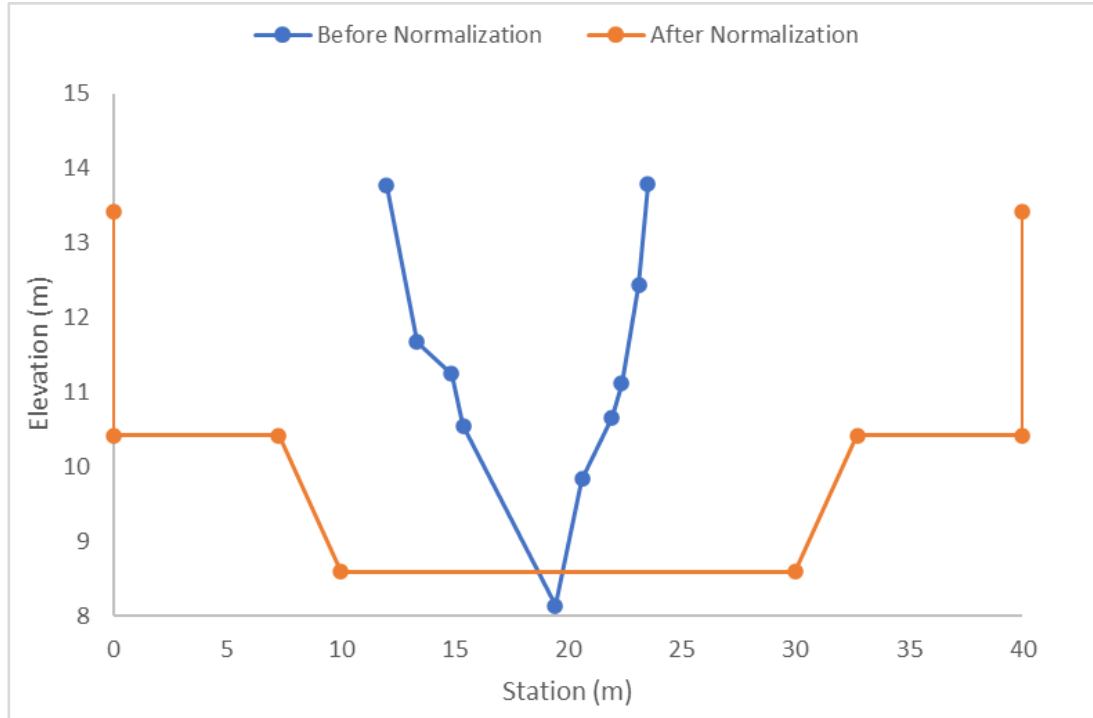

Upstream Section

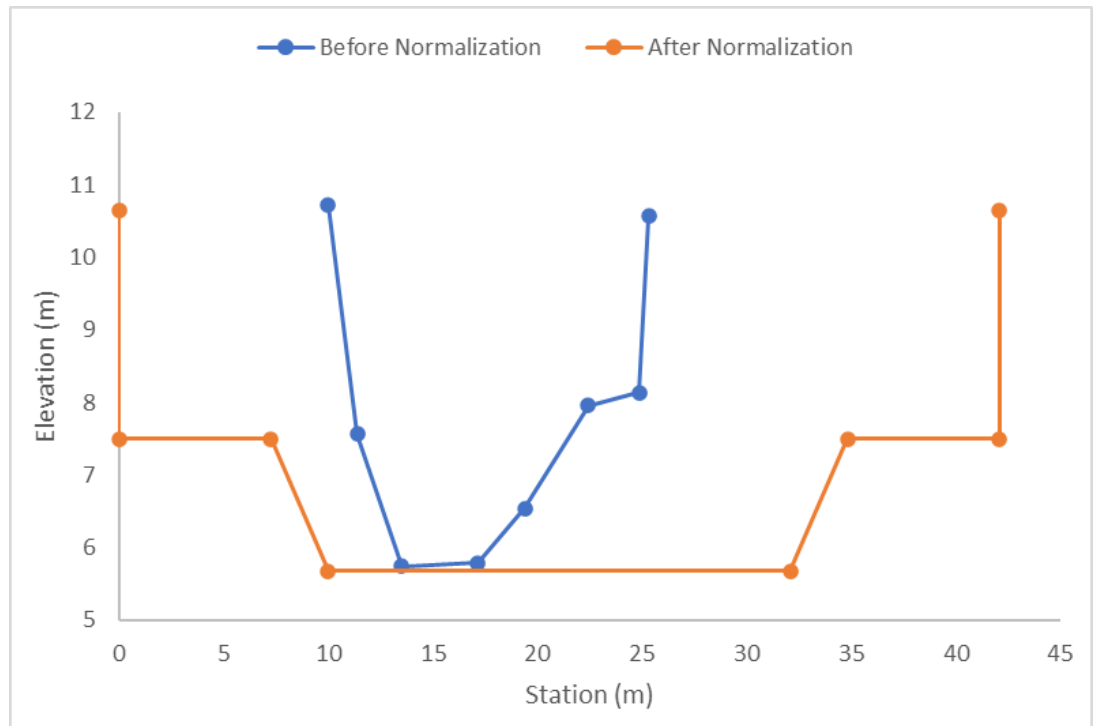

Middle Section 


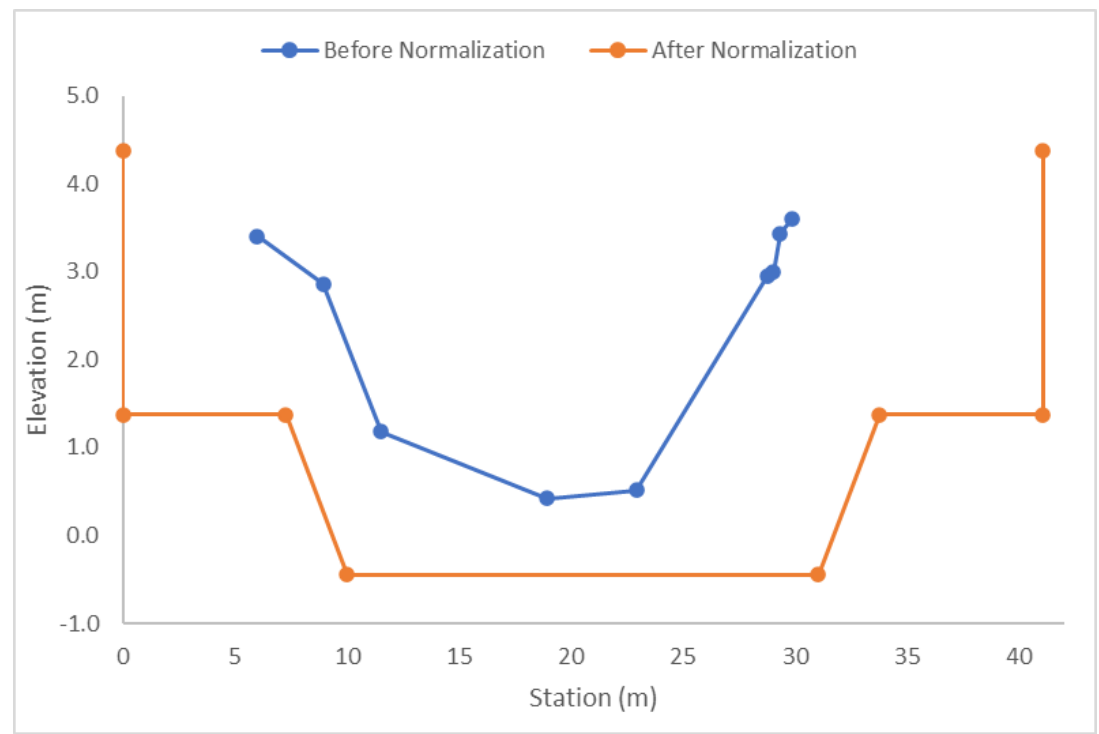

Downstream Section

Figure 5. The change of cross-section of the channel

\section{Methods}

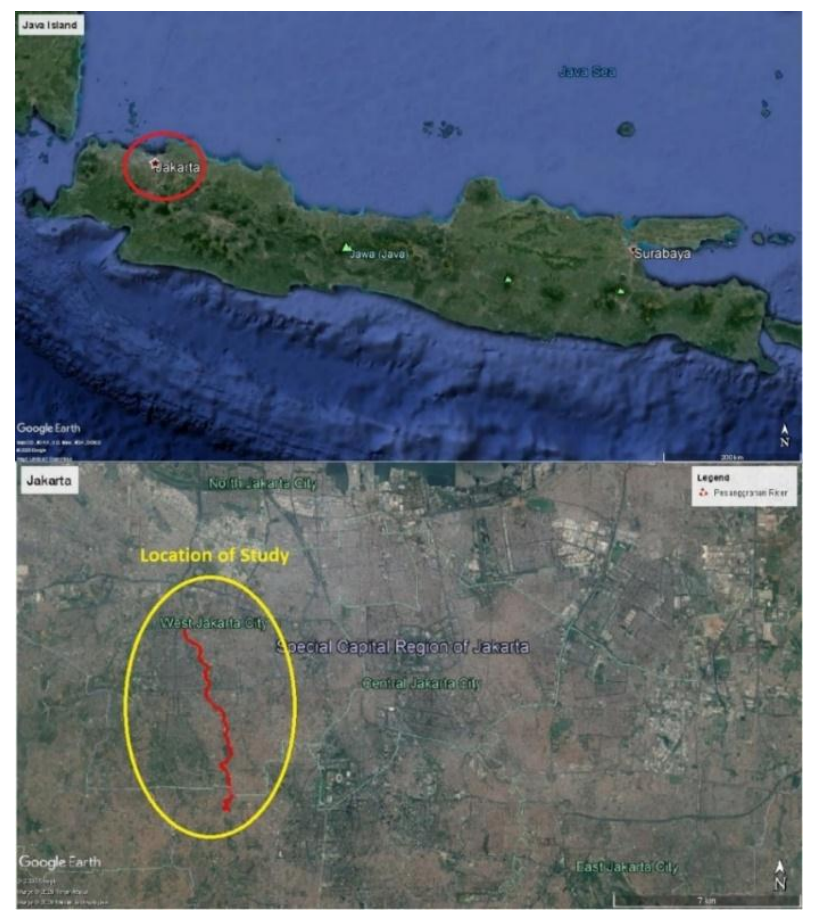

Figure 6. Location of study

The location of the study can be seen in Figure 6 located in the Pesanggrahan River in Jakarta which has been normalized, where the section to be studied is $\pm 9.02 \mathrm{~km}$ starting from South Grogol, Kebayoran Lama to Cengkareng, and Central Jakarta. There are three zones of the longitudinal profile, namely headwater zone, transfer zone, and depositional zone (Schumm, 1977). The location of the study is in the depositional zone which means the section has a lower slope and lower velocity flow, but it has higher depth, a width of the channel, and relative volume of stored alluvium (Garde, 2006).

The first step of this research is to collect secondary and primary data, while secondary data is obtained from literature studies related to research and primary data is obtained from direct observation to the research location to obtain an overview of the current conditions in the field. Secondary data used in this study is geometric data from a cross-section of longitudinal and transverse rivers for conditions with and without normalization and flow rate data that occurred in river sections which were reviewed in the year before Normalization and after Normalization. The primary data used in this study is sediment data taken at the river segment reviewed where there are 3 locations on the river section to take sediment samples.

The next step of the study is river modelling with HEC RAS program which is used because it is suitable based on available data. River modelling in HEC - RAS for sediment transport needs 3 main data which are: geometry river data, flow data, and sediment data. Sediment transport modelling in HEC - RAS is performed in 2 conditions of the river which are before and after Normalization. The geometric data of the river consist of 2 types which are cross-sectional and longitudinal profile. The first thing is to draw the river schematic for the studied reach, and Figure 7 shows the longitudinal profile of the river reach with the cross-section numbers along the river. There are 150 cross-section data at the river reach before Normalization and 130 cross-section data after Normalization. After that, the cross-section data such as the cross-section coordinates and bank stations are input to the program and appeared as in Figure 8. 


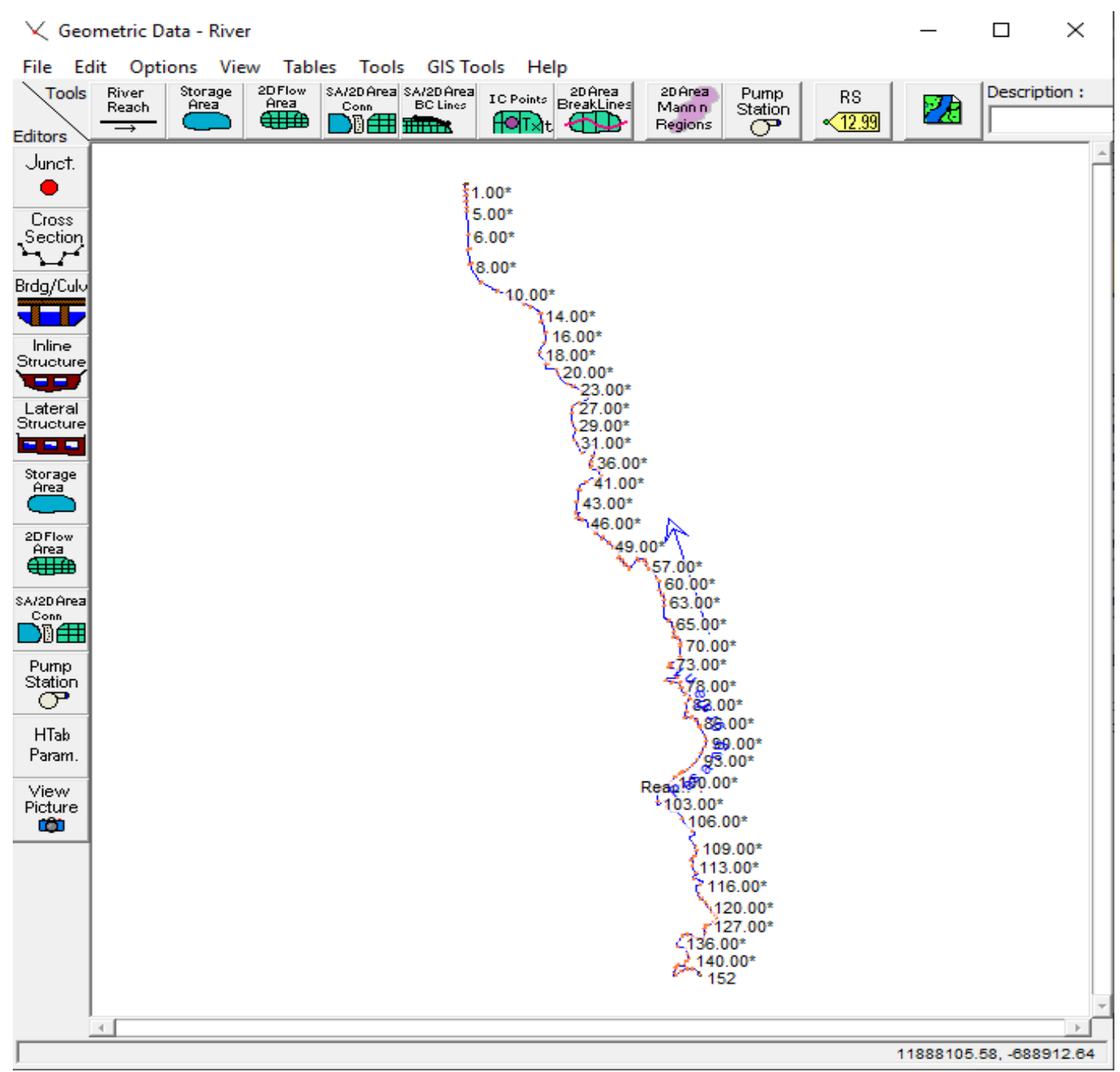

Figure 7. The river reach model

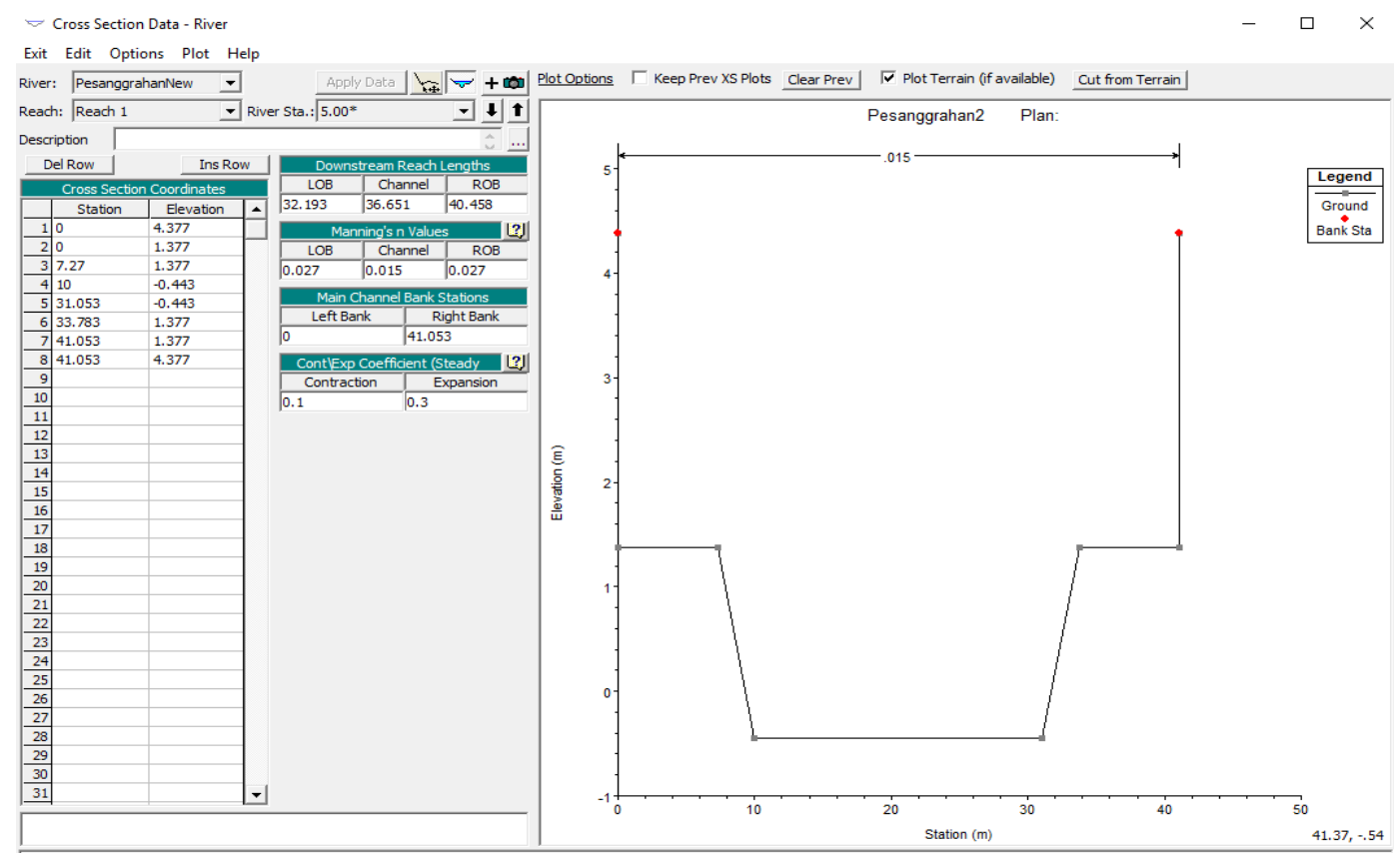

Figure 8. The cross-section geometrical data 
In sediment transport modeling, the dominant discharge is input to the flow data. The boundary conditions used in the flow data is the flow series. From Figure 9, the data used in the flow series is the flow and the flow duration. Since the available flow discharge data is monthly discharge, then the duration of the inputted flow is 1 month. After the flow data input to the program, the gradation of sediment data is input to the initial condition of sediment data at the defined bed gradation. Sediment data input consists of 3 data which are upstream sediment data, middle sediment data, and downstream sediment data as can be seen from Figure 2 .

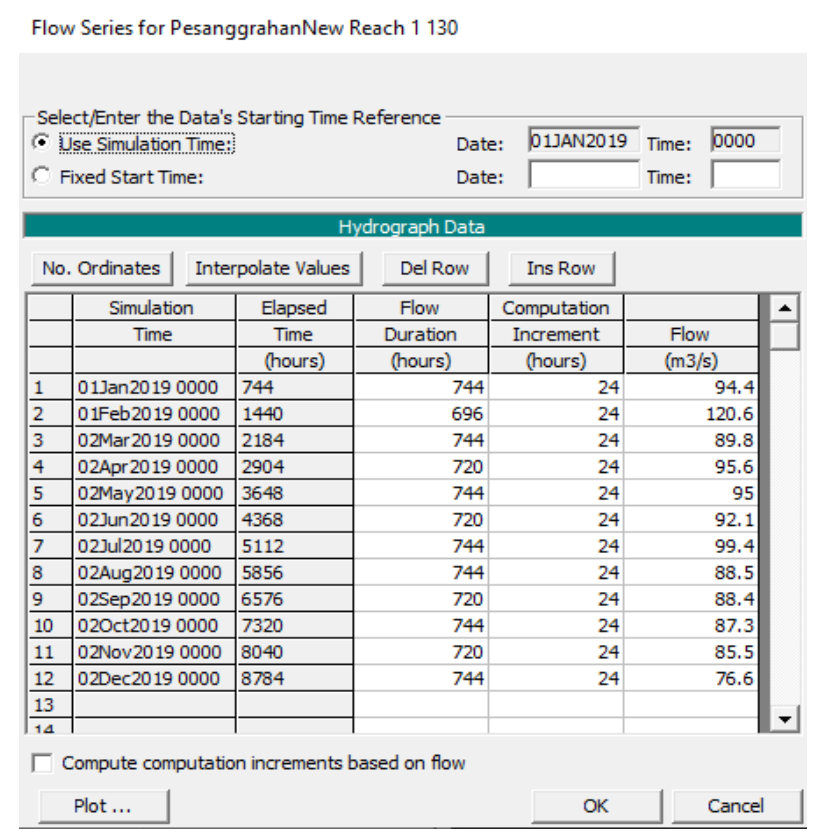

Figure 9. Input menu of flow data

Estimating the amount of sediment transport is quite difficult because it is difficult to get accurate measurements of the amount of bedload both theoretically and in laboratory analysis (Wong \& Parker, 2006). Several methods had been developed to predict sediment transport based on theory and laboratory analysis (McCuen, 1998). Ackers developed one empirical formula used in calculating sediment transport - White, where the sediment transport equation was developed from research data for fine-grained sediments ranging from 0.02 - $4.94 \mathrm{~mm}$ (Department of the Environment, 1990). In this study, Ackers-White formula is used because this formula is suitable to be applied with the sediment grain size of the river.

After all the data obtained, a sediment transport simulation is carried out using HEC - RAS to obtain results in the form of water level. Then, from the water level obtained, it can be known the wet area and circumference of the cross-section of the river. The wet cross-sectional area and circumference that needed to be known is as much as the discharge data that enters the river, which is 12 . It must be done to be able to calculate the rate of sediment transport per year by first calculating sediment transport per month. Therefore, from the result obtained, it can be calculated the sediment transport using Ackers - White equation to determine the rate of sediment transport at the 3 points of sediment sampling in the river segment reviewed.

$$
\begin{gathered}
Q s=Q \cdot X \\
X=\frac{S \cdot D}{H}\left(\frac{V}{U^{*}}\right)^{n} G_{g r}
\end{gathered}
$$

Where

$$
\begin{gathered}
G_{g r}=C\left(\frac{F_{g r}}{A}-1\right)^{m} \\
D_{g r}=D\left[\frac{g(s-1)}{v^{2}}\right]^{1 / 3} \\
F_{g r}=\left[\frac{v_{0}}{\sqrt{g \cdot D \cdot(s-1)} \cdot \sqrt{32 \cdot \log \frac{\alpha H}{D}}}\right]\left[\frac{U *}{V} \sqrt{32} \log \frac{\alpha H}{D}\right]^{n}
\end{gathered}
$$

With the relation of constant values is as follows:

$$
\begin{gathered}
n=\left\{\begin{array}{c}
1.0 \text { for } D_{g r} \leq 1 \\
1-0.56 \log \left(D_{g r}\right) \text { for } \leq D_{g r} \leq 60 \\
0 \text { for } D_{g r}>60
\end{array}\right. \\
m=\left\{\begin{array}{c}
\frac{9.66}{D_{g r}}+1.34 \text { for } D_{g r} \leq 60 \\
0.17 \text { for } D_{g r}>60
\end{array}\right. \\
A=\left\{\begin{array}{c}
\frac{0.23}{\sqrt{D_{g r}}}+0.14 \text { for } D_{g r} \leq 60 \\
1.5 \text { for } D_{g r}>60
\end{array}\right.
\end{gathered}
$$

$\log C$

$$
=\left\{\begin{array}{c}
2.86 \log D_{g r}-\left(\log D_{g r}\right)^{2}-3.53 \text { for } D_{g r} \leq 60 \\
0.25 \text { for } D_{g r}>60
\end{array}\right.
$$

Where:

$\mathrm{D}=$ sediment diameter $(\mathrm{mm})$

$v=$ viscosity

Dgr = dimensionless grain diameter

$\mathrm{H}=$ water depth $(\mathrm{m})$

$\mathrm{S}=$ sediment grain density to water density ratio

Fgr = mobility function

$\mathrm{V}=$ mean water velocity $(\mathrm{m} / \mathrm{s})$

$\alpha=$ constant value (according to Ackers $=12.3$ )

$\mathrm{U}^{*}=$ shear velocity

$\mathrm{A}, \mathrm{C}, \mathrm{n}, \mathrm{m}=$ constant value depending on Dgr

However, before the calculation of rate sediment transport can be done, the hydraulic radius should be calculated first. The hydraulic radius can be calculated from data of wet area and circumference to calculate the shear velocity of each section of the river. After knowing the value of the 12 hydraulic radiuses of each cross-section, the value of the sediment transport can be calculated using Ackers-White equation. 


\section{Result and Discussion}

The result of calculation using Ackers - White formula is the amount of sediment transport per month at the upstream, middle, and downstream areas. It can be seen from Figure 10 to Figure 11 that the sediment transport tends to decrease in number as it approaches closer to the downstream. This happens because the Ackers - White equation calculates the flow velocity of the river, which tends to decrease due to the widening of the cross-section both before and after Normalization (Breusers, 1980). However, the amount of sediment transport after
Normalization tends to be greater than before Normalization. This is due to the widening of the river in Normalization, which makes the amount of bedload transported larger than before the Normalization and shortening the river and increasing the slope, which makes the flow rate increase. However, at a downstream area, the amount of sediment transport tends to be smaller after Normalization, this is due to the cross-section of the river widening downstream so that it reduces flow velocity and affects the amount of sediment transport calculated using the Ackers - White equation.

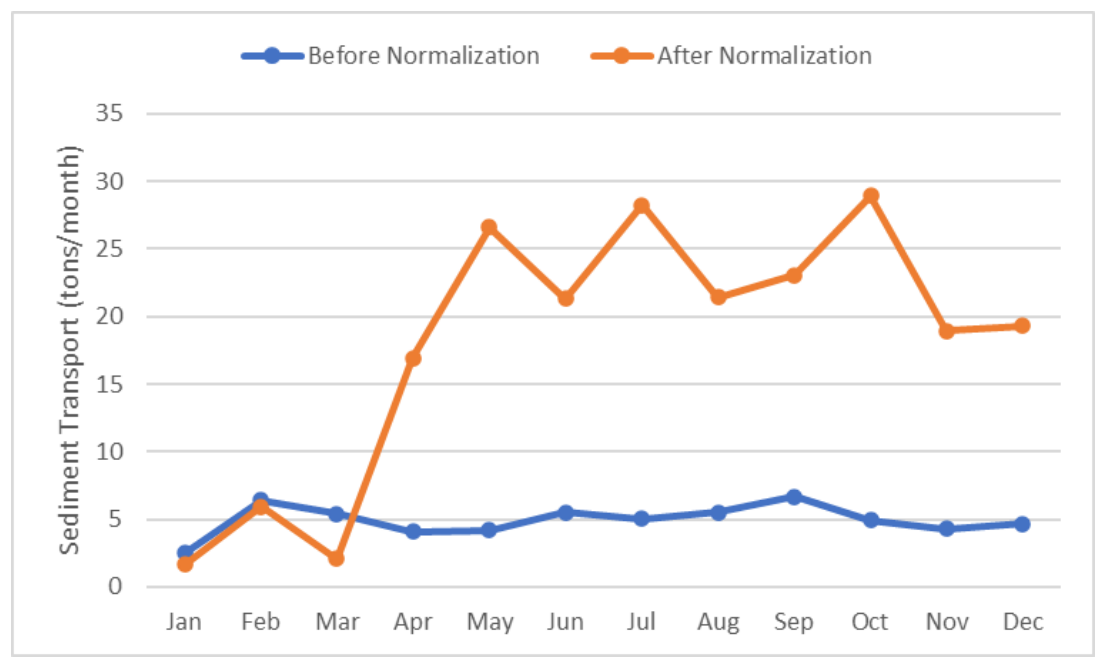

Figure 10. Upstream segment sediment transport

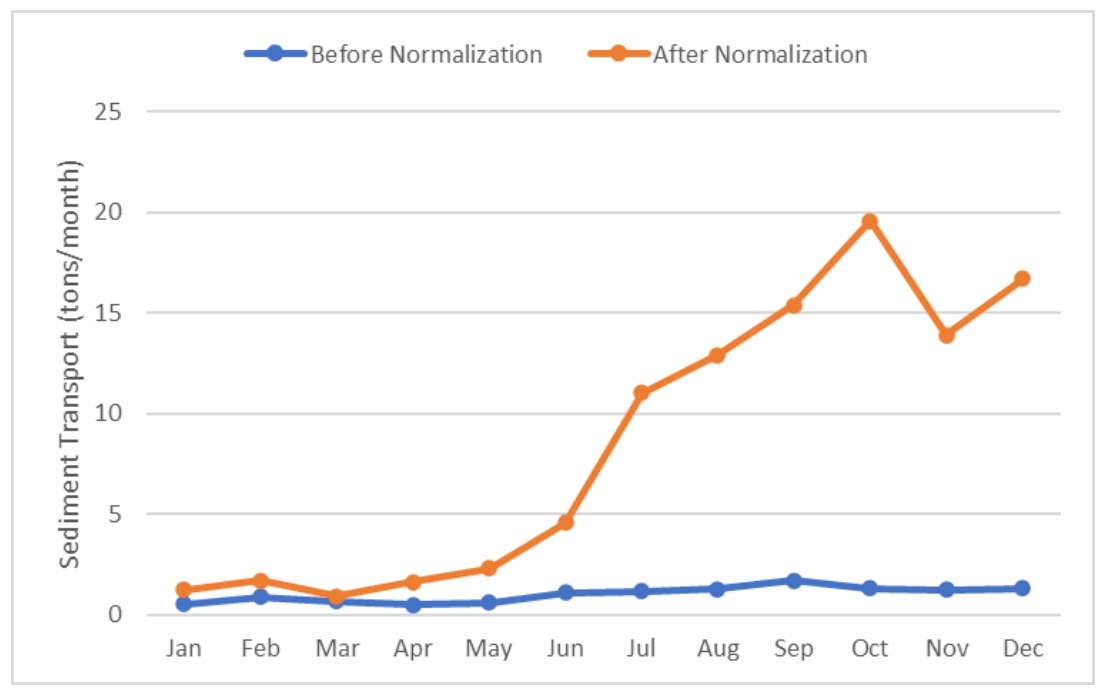

Figure 11. Middle segment sediment transport 


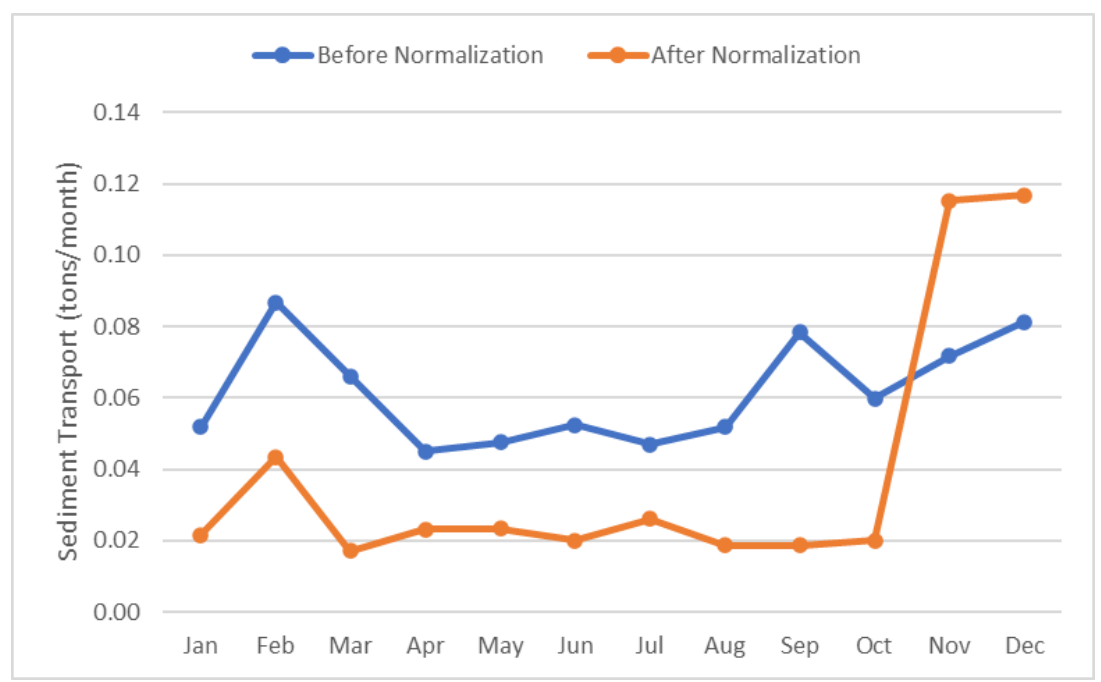

Figure 12. Downstream segment sediment transport

\section{Conclusions}

Based on the results of research and studies on parts of the Pesanggrahan River from upstream in the South Grogol area, Kebayoran Lama District to downstream in the Cengkareng area, Central Jakarta along the $9.02 \mathrm{~km}$, it can be concluded that Normalization of the river by aligning and installing plaster on both riverbanks along the $9.02 \mathrm{~km}$ will affect the shape of the river channel in terms of the profile lengthwise or transversely. With a change in the profile of the river in a transverse and longitudinal direction, it will affect the amount of sediment transport that occurs along with the flow due to the alignment or cutting of several parts of the winding river channel and the installation of plaster on both river banks so that changes in sediment transport occur in the upstream, middle and downstream of the river channel being reviewed. From the simulation using HEC - RAS and the calculation of sediment transport using the Ackers - White equation, it can be seen that the amount of sediment transport in the upstream region has increased from 59.29 tons/year to 214.4 tons/year, in the middle area has increased from 12.18 tons/year to 101.82 tons/year, and downstream areas decreased from 0.74 tons/year to 0.46 tons/year. The results of sediment transport in the downstream area have decreased due to cross-section widening so that there has been a decrease in flow velocity. It happens because the river flow velocity is directly proportional to the amount of sediment transport. Subsequently, if the sediment supply in the upstream area is significantly high, there may be a siltation problem in the downstream area. From this conclusion, it is necessary to reconsider in normalizing the river to deal with floods, so the impact normalization in the form of erosion and sedimentation does not give greater problems in the future. Moreover, further action is needed on sediments that have accumulated in the downstream area as a result of river normalization.

\section{Acknowledgements}

The author would like to thank Universitas Indonesia for the financial support through the research funding scheme "Hibah Penugasan Publikasi Internasional Terindeks 9 (PIT 9)" the fiscal year 2019 number NKB-0053/UN2.R3.1/HKP.05.00/2019.

\section{REFERENCES}

[1] Benson, M. A., \& Thomas, D. M. (2010). A Definition of Dominant Discharge. Hydrological Sciences Journal, 76-80.

[2] Blench, T. (1957). Regime Behaviour of Canals and Rivers. London: Butterworth.

[3] Breusers, H. (1980). Sediment Transport 1. Delft: International Course in Hydraulic Engineering.

[4] Brookes. (1988). Channelized rivers: Perspectives for Environmental Management. Earth Surface Processes and Landforms, 326.

[5] Craig, R. F. (2004). Craig's Soil Mechanics. New York: Spon Press.

[6] Department of the Environment. (1990). Sediment Transport: The Ackers and White Theory Updated. Wallingford: HR Wallingford.

[7] Fondriest Environmental, Inc. (2014, December 5). Sediment Transport and Deposition. Retrieved from Fondriest Environmental Learning Center: https://www.fon driest.com/environmental-measurements/parameters/hydrol ogy/sediment-transport-deposition/

[8] Garde, R. (2006). River Morphology. New Delhi: New Age International (P) Ltd.

[9] McCuen, R. H. (1998). Hydrologic Analysis and Design. New Jersey: Prentice-Hall, Inc. 
[10] Mohammed, H. S., Alturfi, U. A., \& Shlash, M. A. (2018). Sediment Transport Capacity in Euphrates River At Al-Abbasia Reach. International Journal of Civil Engineering and Technology, 919-929.

[11] Prins, A. (1969). Dominant Discharge. Delft: Waterloopkundig Laboratorium.

[12] Prins, I. A. (1970). Rivers. Delft.

[13] Schumm, S. A. (1977). The Fluvial System. New York: John Wiley and Sons.

[14] Soar, P. J., \& Thorne, C. R. (2001). Channel Restoration Design for Meandering Rivers. Washington DC: U.S. Army Corps of Engineers.

[15] Strahler, A. N. (1964). Quantitative Geomorphology of Drainage Basins and Channel Networks. In V.T. Chow, Handbook of Applied Hydrology (pp. 4-39 to 4-76). New York: McGraw Hill Book Company Ltd.
[16] The Federal Interagency Stream Restoration Working Group. (2001). Stream Corridor Restoration. United State: USDA.

[17] US Army Corps of Engineer. (2000). Channel-Forming Discharge. Vicksburg: US Army Corps of Engineer.

[18] US Army Corps of Engineer. (2016). HEC-RAS River Analysis System. Davis: Institute for Water Resources.

[19] Ward, A., D'Ambrosio, J. L., \& Witter, J. (2008). Channel-Forming Discharges. Ohio: The Ohio State University.

[20] White, W. R., Bettes, R., \& Shiqiang, W. (1986). A Study on River Regime. Wallingford: Hydraulic Research.

[21] Wong, M., \& Parker, G. (2006). One-Dimensional Modeling of Morphodynamic Bed Evolution in A Gravel-Bed River Subject. JGE-Earth Surface, 1 - 41.

[22] Worcester, P. G. (1948). A Text Book of Geomorphology. New York: D. Van Nostrand Co. Inc. 